재발한 혼합 간세포 담관상피암종 및 저혈관성 간세포암종 동시 절제 1 예

김태형 ${ }^{1} \cdot$ 엄순호 $^{1} \cdot$ 박상정 $^{1} \cdot$ 박승운 $^{1} \cdot$ 이한아 $^{1} \cdot$ 서연석 $^{1} \cdot$ 유영동 $^{2} \cdot$ 김동식 $^{2} \cdot$ 김주영 $^{3}$

고려대학교 안암병원 ${ }^{1}$ 내과, ${ }^{2}$ 외과, ${ }^{3}$ 병리과

\title{
A Case of Simultaneous Resection of Recurrent Combined Hepatocellular Cholangiocarcinoma and Hypovascular Hepatocellular Carcinoma
}

Tae Hyung Kim', Soon Ho Um', Sang Jung Park', Seung Woon Park', Han Ah Lee', Yeon Seok Seo', Young Dong Yu², Dong-Sik Kim ${ }^{2}$, Joo Young Kim ${ }^{3}$

Departments of ${ }^{1}$ Internal Medicine, ${ }^{2}$ Surgery, and ${ }^{3}$ Pathology, Korea University Anam Hospitial, Seoul, Korea

Received Dec. 20, 2016

Revised Jan. 9,2017

Accepted Jan. 11, 2017
Liver cancer is more complex to treat compared to cancers in other organs, since liver function should be considered. In addition, only a few patients can be applied curative treatment due to advanced stage at diagnosis. Therefore, early stage detection is important and has been increased through screening and surveillance programs using image modalities recently. However, it is still difficult to diagnose small or hypovascular hepatocellular carcinoma (HCC) even using advanced image modalties. In particular, hypovascular HCCs do not show arterial contrast enhancement which is a typical finding of HCC on computed tomography (CT) and magnetic resonance imaging (MRI). Those also account for a considerable portion of early HCC. We present 54 yearsold man who had recurrent hypervascular and hypovascular nodules on three phase CT and gadoxetic acid-enhanced MRI. The nodules were removed by surgical resection and confirmed as combined hepatocellular-cholangiocarcinoma and well differentiated HCC respectively. (J Liver Cancer 2017;17:94-99)

Keywords: Hepatocellular carcinoma; Magnetic resonance imaging; Early diagnosis

\section{서 론}

간암은 치료에 간기능도 같이 고려한다는 점에서 다른 장 기의 암에 비해 치료가 복잡하다. 그리고 진단 시 대개는 진 행된 상태로 근치적 치료가 가능한 경우가 많지 않다. 따라 서 간암은 조기 진단이 중요하며 고위험 간질환 환자를 대

\footnotetext{
Corresponding author: Soon Ho Um

Division of Gastroenterology and Hepatololgy, Department of Internal Medicine, Korea University Anam Hospitial, 73 Inchon-ro, Seongbuk-gu, Seoul 02841, Korea

Tel. +82-2-920-5699, Fax. +82-2-953-1943

E-mail; umsh@korea.ac.kr
}

상으로 감시(surveillance) 검사 프로그램이 진행되면서 조 기 간암이 발견되는 경우가 증가하고 있다. 이런 조기간암 중에 저혈관성 간세포암종이 포함되어 있는데, 한 연구에서 등록된 $3 \mathrm{~cm}$ 이하의 단일 간세포암종 중 $18 \%$ 를 차지할 정 도로 그 비중이 적지 않으나, ${ }^{1}$ 간세포암의 전형적 소견 중 하 나인 동맥기 조영증강을 보이지 않아 현재 진단 기준 ${ }^{2,3}$ 에서 는 조직의 병리학적 검사를 통해서만 진단을 내릴 수 있다. 그러나 조직생검은 간기능 저하에 따른 출혈 또는 복수로 인한 접근 어려움, 암종 전파의 위험 $(0.5-5 \%)^{4}$ 및 높은 위음 성 등 적지 않은 단점들을 갖고 있다. Gadoxetic acid를 이용 한 조영증강 magnetic resonance imaging (MRI) (gadoxetic acid MRI)가 등장하면서 이를 이용하여 저혈관성 간세포암 종을 진단을 보완하려는 연구들이 활발해졌다. 그 결과 간 
세포시기의 결손은 저혈관성 간세포암종 발견을 용이하게 하였으며 이를 통해 진단 민감도(sensitivity)를 11-26\% 더 높일 수 있었다. ${ }^{6,7}$ 그러나 일부 형성이상 결절도 간세포시기 결손을 보이는 경우가 있었으며 여러 연구에서 MRI의 T2 강조영상이나 확산강조영상을 이용하여 이를 구별하고자 하였다. ${ }^{8,9}$ 저자들은 간세포암종 치료 후 40 개월만에 재발한 간세포암종과 gadoxetic acid MRI에서 변화를 보인 저혈관 성 결절에 대해 수술적 치료를 진행하여 간세포암종을 확인 한 사례를 소개하고자 한다.

\section{증 례}

\section{1. 임상소견}

54세 남자로 9년 전 만성 B형 간염으로 인한 간경변을 진 단받고 테노포비어(tenofovir disoproxil)를 복용하는 중이 었다. 약 3 년 전 감시검사로 시행한 역동적 조영증강 복부 전산화 단층 촬영(computed tomography, CT)에서 $2 \mathrm{~cm}$ 가 량의 간세포암종이 발견되었다. 당시 alpha-fetoprotein (AFP)은 $5.0 \mathrm{ng} / \mathrm{mL}$ 로 정상이었으며 Child-Pugh score는 5점 이었다. 입원하여 경동맥 화학색전술(transarterial chemoembolization, TACE) 및 고주파열치료술(radiofrequency ablation, RFA)을 진행하였고, 이후 완전관해를 보였다. 치 료 후 40 개월만에 역동적 조영증강 CT에서 재발 소견이 보 여 입원하였다. 한 달에 1-2회 맥주 1-2병 음용하였으며 30
년 동안 하루 1 갑의 흡연력 있었으나 간경변 진단 후 끊은 상태였다. 내원 당시 이학적 검사상 특이 소견은 없었으며 시행한 혈액검사 결과는 백혈구 $10,200 / \mathrm{mm}^{3}$ (호중구 $56.0 \%$ ), 혈색소 $15.9 \mathrm{~g} / \mathrm{dL}$, 혈소판 $159,000 / \mathrm{mm}^{3}$, 생화학 검사 에서 알부민 $4.5 \mathrm{~g} / \mathrm{dL}$, blood urea nitrogen (BUN) $20.2 \mathrm{mg} / \mathrm{dL}$, creatinine $1.05 \mathrm{mg} / \mathrm{dL}$, aspartate transaminase/alanine transaminase (AST/ALT) 36/33 IU/L, alkaline phosphatase 114 IU/L, gamma glutamyl transpeptidase $44 \mathrm{IU} / \mathrm{L}$, 총 빌리루빈 0.59 $\mathrm{mg} / \mathrm{dL}$, prothrombin time 12.5 초(international normalized ratio [INR] 0.94), 바이러스간염표지자 검사상 $\mathrm{HBs} \mathrm{Ag}(+)$, anti-HBs Ab (-), anti-HCV Ab (-)였으며, $\mathrm{HBV} \mathrm{DNA}$ 는 검출 가능량 미만이었다. 종양표지자 검사상 $\mathrm{AFP} 2.3 \mathrm{ng} / \mathrm{mL}$, protein-induced by vitamin K antagonist-II (PIVKA-II) 19 $\mathrm{mAU} / \mathrm{mL}$ 로 측정되었다. Indocyanine Green test 15 분 정체 율은 $21.0 \%$ 를 보였다.

\section{2. 영상소견}

약 3 년 전 시행한 역동적 조영증강 CT에서 우간 하구역 (segment 5/6)에 $2 \mathrm{~cm}$ 가량의 결절이 보이며, 이 결절은 동맥 기 조영증강과 지연기 조영감소를 보였다. 그리고 우간 전 상분절(segment 8)에 동맥기, 문맥기 및 지연기에 걸쳐 약간 의 저밀도를 보이는 $2 \mathrm{~cm}$ 가량의 결절이 관찰되었다. 그리 고 간표면의 결절성 및 간엽의 비균일적 위축 등 간경변의 소견을 보였다. 정확한 진단을 위해 gadoxetic acid MRI를
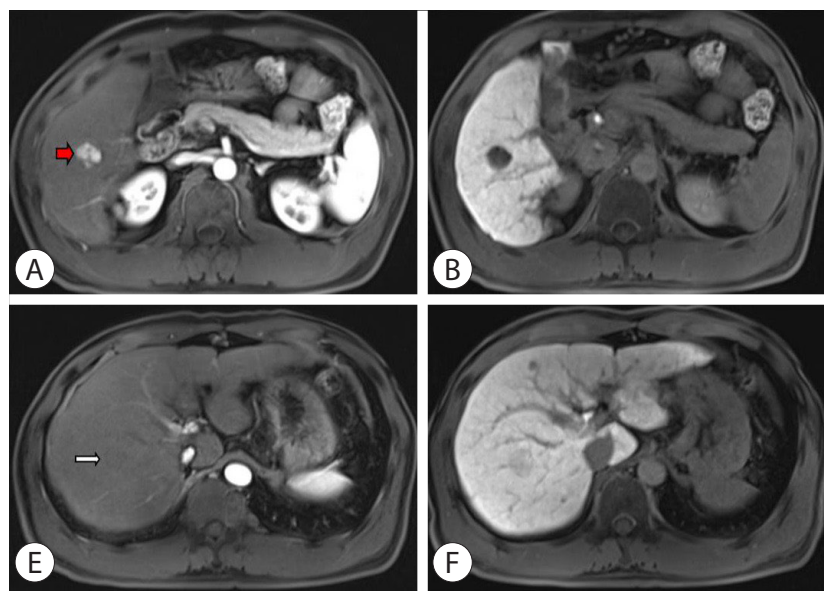
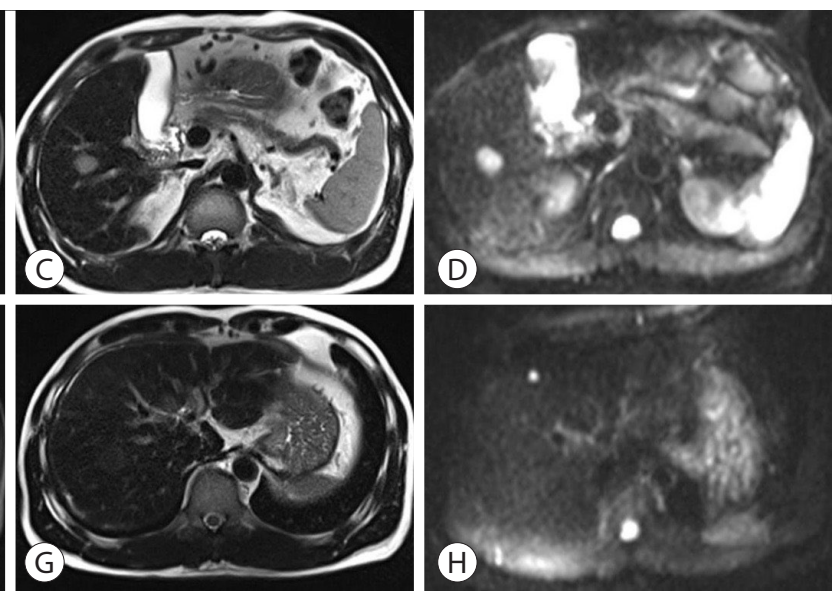

Figure 1. Gadoxetic acid magnetic resonance imaging 40 months ago. (A-D) Images of $2.0 \mathrm{~cm}$ sized hepatocellular carcinoma (red arrow) on segment 5/6 shown on arterial enhance, hepatobiliary, T2 weighted, and diffusion weighted phases, respectively. (E-H) Images of $2.0 \mathrm{~cm}$ sized hypovascular nodule (white arrow) on segment 8 shown on arterial enhance, hepatobiliary phase, T2 weighted, and diffusion weighted phases, respectively. 

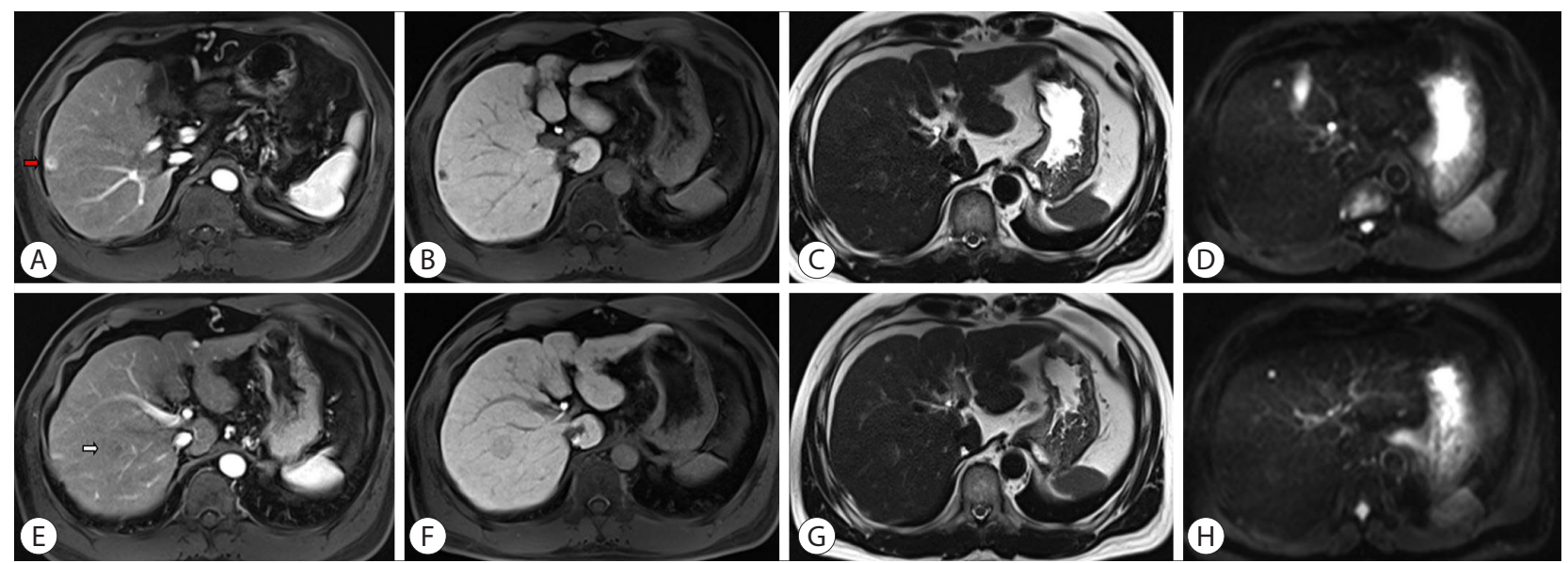

Figure 2. Gadoxetic acid magnetic resonance imaging of recurrent hepatocellular carcinoma (HCC). (A-D) Images of $1.2 \mathrm{~cm}$ sized recurrent HCC (red arrow) on segment 5/6 shown on arterial enhance, hepatobiliary, T2 weighted, and diffusion weighted phases, respectively. (E-H) Images of $2.0 \mathrm{~cm}$ sized hypovascular nodule (white arrow) on segment 8 shown on arterial enhance, hepatobiliary, T2 weighted, and diffusion weighted phases, respectively. Signal intensity in $\mathrm{T} 2$ and diffusion weighted phases were slightly increased more than before.

추가로 시행하였다. CT에서 관찰되었던 $2 \mathrm{~cm}$ 크기의 조영 증강 결절은 마찬가지로 동맥기 조영증강 및 지연기 조영감 소, 간세포시기 결손을 보여 간세포암종으로 진단할 수 있 었다(Fig. 1A-D). 그리고 우간 전상분절에 보이는 저밀도의 결절은 동맥기 및 간세포시기에서 약간의 저신호 강도, $\mathrm{T} 2$ 강조영상 및 확산강조영상에서 주변 간실질과 동등한 신호 강도를 보여 형성이상 결절(dysplastic nodule)이 고려되었 다(Fig. $1 \mathrm{E}-\mathrm{H}$ ). 그 이외에 간내 전이 등의 의미있는 병변은 보이지 않았다. TACE 및 RFA 후 시행한 CT에서는 이전 간 세포암에 리피오돌이 잘 침착되었으며 그 외 동맥기 조영증 강되는 병변은 보이지 않았다.

이번에 시행한 역동적 조영증강 CT에서 우간 후상분절 (segment 7)에 동맥기 조영증강과 지연기 조영감소가 보이 는 $1.2 \mathrm{~cm}$ 가량의 결절이 발견되었다. 그리고 이전에 보였 던 우간 전상분절에 보였던 저밀도의 결절은 크기 변화 없 이 같은 양상을 보였다. 이전 치료 부위 및 그외 부위에서 동맥기 조영증강되는 병변은 보이지 않았다. 다시 정확한 진단을 위해 역동적 조영증강 $\mathrm{MRI}$ 를 추가로 시행하였으 며, CT에서 보인 조영증강된 병변은 동맥기 조영증강 및 지연기 조영감소, 간세포시기 결손을 보였다(Fig. 2A-D). 우간 전상분절에 보이는 저밀도의 결절은 동맥기 및 간세 포시기에서 약간의 저신호 강도는 이전과 차이가 없었으 나, T2 강조영상 및 확산강조영상에서 주변 간실질에 비해 약간의 고신호 강도를 보여 이전과 다른 양상을 보였다 (Fig. 2E-H).

\section{3. 진단 및 치료 경과}

처음 발견되었던 $2 \mathrm{~cm}$ 의 간세포암에 대해 영상 검사에 따 른 병기상 Modified Union for International Cancer Control (mUICC) T1N0M0로 stage I으로 진단되었다. 치료를 시행 하고 40개월만에 시행한 CT 및 gadoxetic acid MRI에서 후 기 재발(late recurrence)한 간세포암종을 진단할 수 있었다. 다만 우간 전상분절의 저밀도 병변은 크기 변화는 없으나 gadoxetic acid MRI에서 신호강도의 변화를 보여 고등도 형 성이상 결절 고등도(high grade dysplastic nodule) 또는 조기 간세포암종(early HCC)을 의심할 수 있었다. 전자일 경우 mUICC T1N0M0로 stage I에, 후자일 경우 mUICC T2N0M0로 stage II에 해당하여 치료로 두 개 병변에 대해 수술적 절제를 시행하였다. 수술에서 전이나 복막 파종 등 의 소견은 보이지 않았다. 이후 별다른 합병증 없이 퇴원하 였고 11 개월 동안 완전관해를 유지 중이다.

\section{4. 병리소견}

$1.2 \mathrm{~cm}$ 의 우간 후상분절 병변의 병리소견은 과염색된 비 정형 세포(hyperchromatic atypical cell)들이 샘 모양 또는 덩 어리 모양을 띠어 중등도 및 저등도 분화를 보이며 cytokeratin 7 면역 염색에 양성을 보여 담관상피암종을 진단하였 고(Fig. $3 \mathrm{~A}, \mathrm{~B}$ ), 명확하게 구분을 이루지는 않지만 그 안에 간세포 형태로 자리잡은 glypican 면역염색 양성 소견을 보 

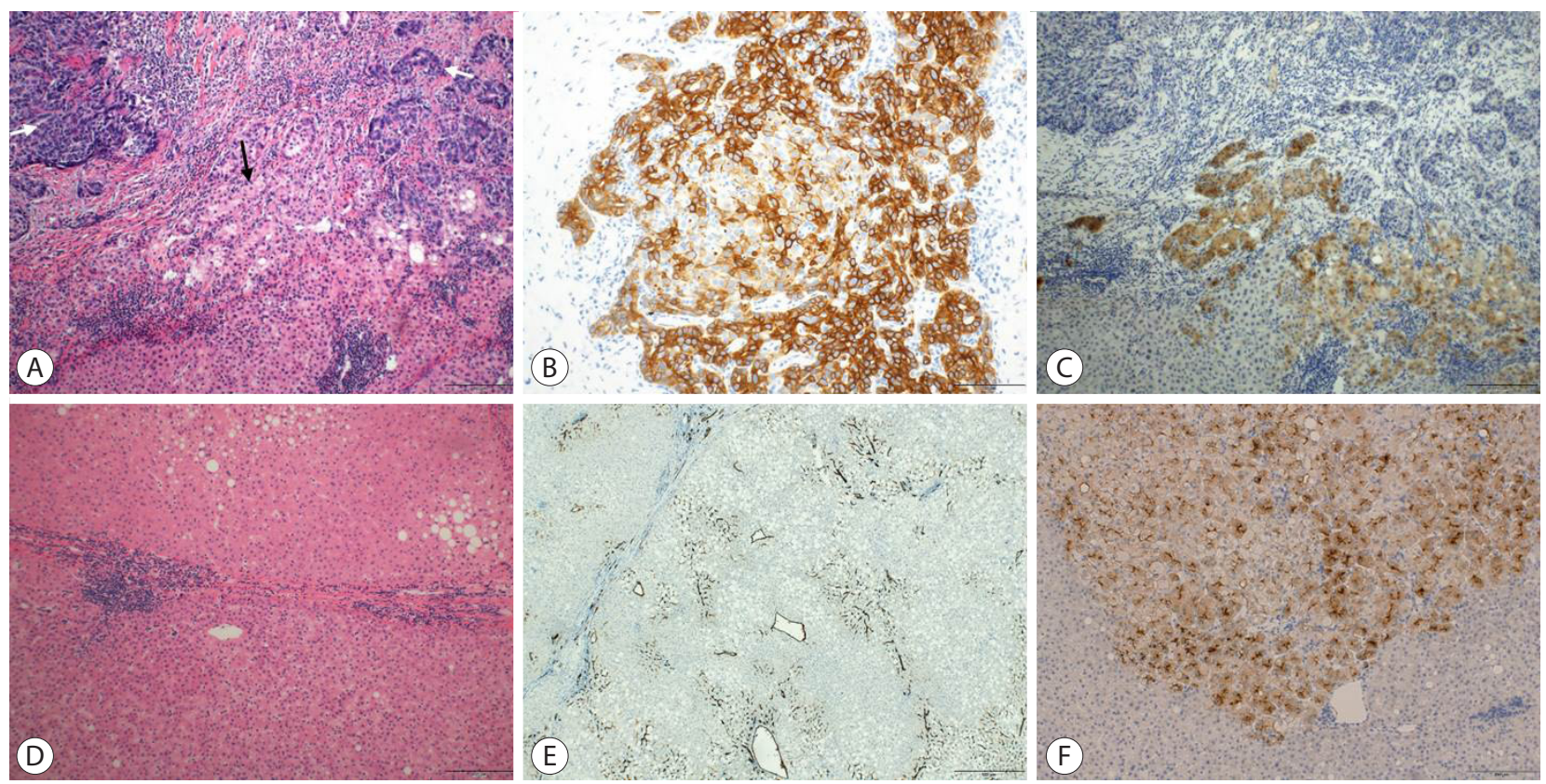

Figure 3. Pathological findings. (A-C) Combined hepatocellular-cholangiocarcinoma. (A) Hyperchromatic atypical cells are seen in glandular and solid forms (white arrows), and deformed hepatocytes are seen on center (black arrow), $\times 200$. (B) Cholangiocarcinoma components are strongly positive for Cytokeratin 7 immunohistochemistry, $\times 400$. (C) Hepatocellular carcinoma components are positive for glypican immuohistochemistry, $\times$ 200. (D-F) Well differentiated Hepatocellular carcinoma. (D) The tumor (bottom) shows increased cellularity and sheet like trabecules compared to non-tumoral tissue, $\times 200$. (E) Loss of portal tracts and unpaired arteries are identified, $\times 80$. (F) Tumor cells are focally positive for glypican immunohistochemistry, $\times 200$.

이는 간세포암종을 보여 최종적으로 혼합 간세포-담관상피 암종으로 밝혀졌다(Fig. 3C). $2.0 \mathrm{~cm}$ 의 우간 전상분절의 병 변의 병리소견은 주변세포들과 구별이 어려울 정도로 분화 가 좋으나 세포밀도가 2 배 정도 증가되어 있으며 2층의 종 양세포로 구성된 얇은 육주를 형성하고(Fig. 3D), 간세동이 (portal triad)의 소실과 다수의 담관을 동반하지 않은 동맥 (unpaired artery)이 관찰되며, glypican 면역염색에서 일부 양성소견을 보여주어(Fig. 3E, F) 최종적으로 고등도 분화 간세포암종으로 진단하였다.

\section{고 찰}

Gadoxetic acid MRI가 등장하면서 악성종양을 의미하는 간세포시기 결손을 이용하여 이전 영상에서는 구별되지 않 았던 간의 병변들이 늘어났다. 특히 저혈관성이면서 간세포 시기에서도 저신호강도를 보이는 결절들이 보였으며 이는 대개 저혈관성 간세포암이거나 고등도 형성이상 결절로 두 병변 모두 병리학적으로도 구별하기 쉽지 않아 기질의 침입 을 기준으로 하고 있다. ${ }^{10}$
저혈관성 저신호 결절에 대해 여러 연구들이 활발히 진행 되고 있다. 최근 이 결절이 있으면 과혈관성 간세포암이 3 년 내 발생이 $22 \%$ 에서 나타나며 그 위험비가 9.4 에 달한다는 연구결과들이 있었다. ${ }^{11,12}$ 그리고 다른 연구에 의하면 경과 관찰을 한 두 연구에서 전형적인 간세포암에 대해 수술적 절제나 RFA를 시행 시 저혈관성 저신호 결절이 동반되면 다발성 재발암이 더 흔하게 발생하며 상대위험도는 약 2.8 로 높은 소견을 보였다. ${ }^{1314}$ 따라서 저혈관성 저신호 결절이 과혈관성 간세포암 발생에 중요한 예측인자로서 작용함을 보여주고 있다. 특히 다발성 재발암에 대해서도 예측인자로 작용하여 간세포암의 근치적 치료를 진행하기 전에 gadoxetic acid MRI 시행의 중요성을 보여주었다.

이에 대한 치료효과를 연구한 논문들을 살펴보면 한 연구 에서는 과혈관성 간세포암 절제 시 저혈관성 저신호 결절을 동반절제한 경우 무재발 생존율(recurrence free survival)이 의미 있게 향상되었다. ${ }^{15}$ 그러나 전체 생존율(overall surviv$\mathrm{al})$ 은 큰 차이를 보이지 못하였다. 다른 연구에서도 저혈관 성 조기 간세포암종을 치료하였으나 전형적인 소견의 간세 포암종 치료와 비교하면 선행기간(lead time)으로 인해 생 
존이점(survival benefit)은 약 1.3 개월에 불과하였다. ${ }^{16}$ 즉 저 혈관성 저신호 결절에 대한 적극적인 조기치료는 전체 생존 기간 연장의 명확한 근거가 필요하다. 따라서 적정 치료시 기에 대한 판단이 요구되었고 그 방법으로 과혈관성 간세포 암종으로 변할 위험성이 높은 저혈관성 저신호 결절을 선별 할 필요가 있었다. 다단계 간세포암생성과정을 고려하여 시 행한 연구들에 의하면 1년 동안 $15-43 \%$ 의 저혈관성 저신호 결절들이 전형적인 과혈관성 간세포암종으로 변이를 보였 다. ${ }^{17,18}$ 특히 결절의 크기가 $1.5 \mathrm{~cm}$ 이상, 지방을 포함, $\mathrm{T} 1$ 또 는 T2 강조영상이나 확산강조영상에서 고신호강도, 추적관 찰 시 성장속도가 빠를 경우 추후 고혈관성 간세포암종으 로 변할 가능성이 높은 것으로 최근 연구들에서 보고되었 다. ${ }^{19,20}$

본 증례에서는 과혈관성 간세포암종이 뚜렷한 악성 증거 가 없는 저혈관성 저신호강도 결절을 동반하여, 암종에 대 해서는 RFA 시행하고 결절에 대해서는 경과 관찰하였다. 치료 후 40 개월 만에 다른 분절에서 간세포암종이 재발하였 다. 저혈관성 저신호강도 결절 또한 T2 및 확산 강조영상에 서 이전과 달리 고신호 강도로 변화를 보이고 크기 변화는 없으나 $1.5 \mathrm{~cm}$ 보다 커서 전형적 간세포암종으로 변이 가능 성이 높다고 판단하였으며 두 병변 모두 동시 절제하였다. 병리검사 결과 저혈관성 결절은 간세포암종으로 판별되었 다. 조직 검사가 갖는 단점을 고려할 때 앞으로의 연구들을 통해 비침습적인 방법으로 조기 간세포암종 진단이 가능해 지고 대부분의 간세포암종 환자들에게 적절한 시기에 근치 적 치료를 받을 수 있을 것으로 생각된다.

\section{Conflicts of Interest}

The authors have no conflicts to disclose.

\section{REFERENCES}

1. Takayasu K, Arii S, Sakamoto M, Matsuyama Y, Kudo M, Ichida T, et al. Clinical implication of hypovascular hepatocellular carcinoma studied in 4,474 patients with solitary tumour equal or less than 3 cm. Liver Int 2013;33:762-770.

2. European Association For The Study Of The Liver; European Organisation For Research And Treatment Of Cancer. EASL-EORTC clinical practice guidelines: management of hepatocellular carcinoma. J Hepatol 2012;56:908-943.

3. Bruix J, Sherman M; American Association for the Study of Liver Diseases. Management of hepatocellular carcinoma: an update. Hepa- tology 2011;53:1020-1022.

4. Silva MA, Hegab B, Hyde C, Guo B, Buckels JA, Mirza DF. Needle track seeding following biopsy of liver lesions in the diagnosis of hepatocellular cancer: a systematic review and meta-analysis. Gut 2008:57:1592-1596.

5. Roskams T, Kojiro M. Pathology of early hepatocellular carcinoma: conventional and molecular diagnosis. Semin Liver Dis 2010;30:17-25.

6. Inoue $T$, Kudo M, Komuta M, Hayaishi $S$, Ueda T, Takita M, et al. Assessment of Gd-EOB-DTPA-enhanced MRI for HCC and dysplastic nodules and comparison of detection sensitivity versus MDCT. J Gastroenterol 2012;47:1036-1047.

7. Rhee H, Kim MJ, Park YN, Choi JS, Kim KS. Gadoxetic acid-enhanced MRI findings of early hepatocellular carcinoma as defined by new histologic criteria. J Magn Reson Imaging 2012;35:393-398.

8. Hwang J, Kim YK, Jeong WK, Choi D, Rhim H, Lee WJ. Nonhypervascular hypointense nodules at gadoxetic acid-enhanced MR Imaging in chronic liver disease: diffusion-weighted imaging for characterization. Radiology 2015;276:137-146.

9. Kim YK, Lee YH, Kim CS, Han YM. Added diagnostic value of T2weighted MR imaging to gadolinium-enhanced three-dimensional dynamic MR imaging for the detection of small hepatocellular carcinomas. Eur J Radiol 2008:67:304-310.

10. International Consensus Group for Hepatocellular Neoplasia The International Consensus Group for Hepatocellular Neoplasia. Pathologic diagnosis of early hepatocellular carcinoma: a report of the international consensus group for hepatocellular neoplasia. Hepatology 2009;49:658-664.

11. Ichikawa S, Ichikawa T, Motosugi U, Sano K, Morisaka H, Enomoto N, et al. Presence of a hypovascular hepatic nodule showing hypointensity on hepatocyte-phase image is a risk factor for hypervascular hepatocellular carcinoma. J Magn Reson Imaging 2014;39:293-297.

12. Komatsu N, Motosugi U, Maekawa S, Shindo K, Sakamoto M, Sato M, et al. Hepatocellular carcinoma risk assessment using gadoxetic acidenhanced hepatocyte phase magnetic resonance imaging. Hepatol Res 2014:44:1339-1346.

13. Toyoda H, Kumada T, Tada T, Niinomi T, Ito T, Sone $Y$, et al. Nonhypervascular hypointense nodules detected by Gd-EOB-DTPAenhanced MRI are a risk factor for recurrence of HCC after hepatectomy. J Hepatol 2013;58:1174-1180.

14. Lee DH, Lee JM, Lee JY, Kim SH, Kim JH, Yoon JH, et al. Non-hypervascular hepatobiliary phase hypointense nodules on gadoxetic acidenhanced MRI: risk of HCC recurrence after radiofrequency ablation. J Hepatol 2015;62:1122-1130.

15. Matsuda M, Ichikawa T, Amemiya H, Maki A, Watanabe M, Kawaida H, et al. Preoperative gadoxetic Acid-enhanced MRI and simultaneous treatment of early hepatocellular carcinoma prolonged recurrencefree survival of progressed hepatocellular carcinoma patients after hepatic resection. HPB Surg 2014;2014:641685. 
16. Midorikawa Y, Takayama T, Shimada K, Nakayama H, Higaki T, Moriguchi $M$, et al. Marginal survival benefit in the treatment of early hepatocellular carcinoma. J Hepatol 2013;58:306-311.

17. Sano K, Ichikawa T, Motosugi U, Ichikawa S, Morisaka H, Enomoto N, et al. Outcome of hypovascular hepatic nodules with positive uptake of gadoxetic acid in patients with cirrhosis. Eur Radiol 2017;27:518525.

18. Kumada T, Toyoda H, Tada $T$, Sone $Y$, Fujimori M, Ogawa S, et al. Evolution of hypointense hepatocellular nodules observed only in the hepatobiliary phase of gadoxetate disodium-enhanced MRI. AJR Am J Roentgenol 2011;197:58-63.
19. Kim YS, Song JS, Lee HK, Han YM. Hypovascular hypointense nodules on hepatobiliary phase without $\mathrm{T} 2$ hyperintensity on gadoxetic acidenhanced MR images in patients with chronic liver disease: longterm outcomes and risk factors for hypervascular transformation. Eur Radiol 2016;26:3728-3736.

20. Kim YK, Lee WJ, Park MJ, Kim SH, Rhim H, Choi D. Hypovascular hypointense nodules on hepatobiliary phase gadoxetic acid-enhanced MR images in patients with cirrhosis: potential of DW imaging in predicting progression to hypervascular HCC. Radiology 2012;265:104114. 